\title{
Titae
}

31 (2017) 123-148

Ks. Bartłomiej Sobierajski

Studium Biblicum Franciscanum, Jerusalem, Israel ks.b.sobierajski@gmail.com

\section{MesjańsKi EKOSYSTEM (Iz 11,6-8)}

The Messianic Ecosystem in Isa 11:6-8

Charakterystyka każdego ekosystemu zawiera nie tylko opis gatunków roślin i zwierząt w nim występujących, ale także analizę relacji pomiędzy gatunkami i pomiędzy nimi a ich środowiskiem. Artykuł jest próbą odIzajasz; pokój; mesjanizm; sprawiedliwy władca; Iz 11,6-8; powiedzi na pytanie o naturę mesjańskiego pokoju przedstawionego w Iz 11,6-8, głównie w oparciu o opis czynności i zachowań, które charakteryzujązwierzęta i postaci ludzkie w nim występujące. Takie podejście do tematu uzupełnia liczne i szczegółowe analizy gatunków zwierząt z Iz 11,6-8 oraz próby odczytania ich znaczenia. Według Izajasza pokój nie jest zwykłym brakiem wojny, ale obok harmonijnej koegzystencji i wspólnego zamieszkiwania ludzi zawiera także ideę życia w obfitości pod rządami sprawiedliwego władcy. Takie rozumienie pokoju można dostrzec także w innych częściach ProtoIzajasza, spośród których na szczególną uwagę zasługuje Iz 32. 
Our understanding of any natural ecosystem Isaiah; peace; includes not only a description of the species of plants and animals it encompasses, but also an analysis of the relationships involved, both between the species themselves and between each of them and their environment. The article attempts to answer such questions about the nature of the messianic peace outlined in Isa 11:6-8, an investigation based mainly on the activities and behaviors characteristic of the animals and human figures seen in this passage. Such an approach to the subject complements much previous scholarship, which includes numerous detailed analyses of the species named in Isa 11:6-8, as well as attempts to interpret their meaning. According to Isaiah, peace is not simply the absence of conflict but also involves the harmonious coexistence and cohabitation of people. Still further, it always includes the idea of living in abundance under the dominion of a righteous ruler. This understanding of peace can be seen in various other parts of Proto-Isaiah, especially in Chapter 32.

messianism; righteous ruler;

Isa 11:6-8; Isa 32:2; Isa $32: 17$

Proroctwo mesjańskie Iz 11,1-9 stanowi kunsztowną „perłę poezji hebrajskiej”', która swoje piękno czerpie zarówno z bogactwa leksykograficznego, zastosowania licznych struktur retorycznych, jak również oddziałujących na wyobraźnię obrazów ze świata roślinnego i zwierzęcego. Zawarty we wspomnianym fragmencie obraz pokojowo koegzystujących zwierząt (w. 6-8) wielokrotnie inspirował egzegetów do po-

1 Wildberger, Isaiah 1-12, 465; Alonso Schökel - Sicre Diaz, I Profeti, 183. 
szukiwania ukrytego w nim znaczenia. Badacze skupiają się przede wszystkim na próbach ukazania kontekstu historyczno-kulturowego, w jakim powstało proroctwo, oraz na odczytaniu symboliki w nim zawartej. Definicja ekologii jako nauki zawiera w sobie nie tylko opis gatunków występujących w przyrodzie ${ }^{2}$. Jej przedmiotem są także istniejące wzajemne oddziaływania między organizmami, a także między organizmami a ich środowiskiem. Idąc tym tropem, w poniższym artykule zostanie podjęta próba przedstawienia zależności, jakie występują między wymienianymi w ekosystemie Iz 11,6-8 gatunkami zwierząt. Aby uchwycić wspomnianą dynamikę, główny akcent analizy zostanie postawiony na egzegezie czasowników wyrażających owe zależności, co pozwoli odpowiedzieć na pytanie o istotę mesjańskiego ekosystemu. W końcu poprawność wyciągniętych wniosków zostanie zweryfikowana w świetle analizy kontekstu dalszego, przede wszystkim Iz 32.

\section{Charakter proroctwa Iz 11,6-8}

Wizja nowego świata zawarta w Iz 11,6-8 musi być odczytana w swoim kontekście. Zagadnienia literackie, związane przede wszystkim z delimitacją i strukturą fragmentu, do którego przynależy badana część, a także określenie charakteru całej wyroczni pomogą w zrozumieniu funkcji, jaką pełni proroctwo o mesjańskim ekosystemie. Będzie to punktem wyjścia do szczegółowej analizy zachowań postaci i zwierząt tam występujących.

\subsection{Zagadnienia literackie}

Jak zaznaczyliśmy, fragmentem, do którego przynależą w. 6-8, jest Iz 11,1-9. Jest to najczęściej przyjmowana przez egzegetów

2 Pracą, która w obszerny sposób podejmuje analizę gatunków zwierzęcych występujących w Iz 11,6-8, jest np. artykuł: Wajda, „Zwierzęta mesjańskiego królestwa”, 109-134. 
delimitacja ${ }^{3}$. Rozbieżności od tego głównego nurtu obserwujemy zasadniczo w dwóch punktach. Pierwszym z nich jest początek wspomnianej wyroczni umieszczany przez niektórych w $10,33^{4}$. Od strony syntaktycznej świadczyłaby o tym partykuła hinnēh otwierająca ten wiersz, a także imiesłów masāe ēp rozpoczynający łańcuch waqatal zakończony dopiero w $11,9^{5}$. Od strony treściowej natomiast obraz powalonego lasu w 10,33-34, metaforycznie oznaczającego dotychczasowych władców Izraela, którzy muszą być usunięci, korespondowałby z „odroślą z pnia Jessego” $(11,1)$ oczekiwanym, doskonałym władcą. Obie drogi argumentacji nie wytrzymują jednak konfrontacji. Partykuła binnēb wcale nie musi oznaczać początku nowej sekcji, jej rolą jest przede wszystkim przybliżenie horyzontu wydarzeń: karząca interwencja YHWH w w. 33-34 jest bliska i nieodwołalna. Także powtarzająca się syntagma „Pan YHWH Zastępów” $(10,16.23 .24 .33)$ świadczy o przynależności ostatnich dwóch wersetów Iz 10 do kontekstu poprzedzającego. Z kolei obraz wycinania lasu należy łączyć z upadkiem Asyrii i ukaraniem jej pychy, a nie władców Jerozolimy. Owszem, ścięcie drzew jest kontekstem wprowadzającym nowy pęd, odrośl wyrastającą z pnia, w którego korzeniach jest jeszcze ciągle życiodajna moc (por. 6,13). Należy zauważyć jednak bardzo silne tematyczne powiązanie w. 33-34 przede wszystkim $\mathrm{z}$ w. 15. Cztery przysłowia o pysze (w. 15) niewątpliwie tyczą się Asyrii, terminy sēbett i mațteh (por. 10,5) mają podkreślić funkcję Asyrii jako narzędzia w ręku YHWH, któremu to zadaniu mocarstwo nie chce się podporządkować.

3 Por. Oswalt, The Book of Isaiah, 276; Rumianek, „Potomek rodu Jessego", 99; Sweeney, Isaiah 1-39, 198; Blenkinsopp, Isaiah 1-39, 262; Pikor, „Pytanie o mesjański sens”, 23-24.

4 Por. Kluczyński, „Instytucja monarchii”, 49.

5 Forma qatal na końcu w. 8 nie zamyka sekwencji, lecz pełni funkcję emfatyczną względem poprzedzającego ją podmiotu. Pikor, Soteriologiczna metafora, 104. 
Drugim zasadniczym punktem rozbieżności jest zakończenie wyroczni, przez niektórych sytuowane w $11,10^{6}$. Tworzyłby on inkluzję z w. 1 dzięki powtórzeniu imienia Jesse. Syntagmy związane z tym imieniem są jednak różne: „odrośl Jessego” (w. 1) i „korzeń Jessego” (w. 10). Werset 10 otwiera wyrażenie "stanie się owego dnia” stojące w funkcji terminu początkowego. Powtórzenie tej formuły w w. 11, jak również przejęcie motywu „znaku” (nēs), świadczy raczej o łączności w. $10 \mathrm{z}$ kontekstem następującym, a jego rola jawi się jako redakcyjny łącznik między w. 1-9 i 11-167.

Określenie czasu powstania wyroczni w. 6-8 jest nierozdzielnie związane z poprzedzającą ją częścią Iz 11,1-5. Na podstawie wyrażenia „pień/odrośl Jessego” (w. 1) część egzegetów datuje Iz 11,1-5 na okres po 587 r., argumentując, iż polityczna sytuacja królewskiego domu Dawida jest już znacznie osłabiona, jednak nie zniszczona kompletnie ${ }^{8}$. Jest to zbyt daleko idący wniosek. Obraz ściętego pnia, symbolizujący śmierć króla, wcale nie musi oznaczać końca dynastii, gdyż korzenie tkwiące w ziemi są wciąż żywe i wypuszczają kolejne pędy - nowych władców ${ }^{9}$. Kwestionowanie Izajaszowego autorstwa w. 6-8 opiera się przede wszystkim na założeniu, że eschatologiczna wizja powinna być obca historycznej osobie proroka. Jednak obraz pokojowej egzystencji w przemienionym świecie da się zauważyć zarówno w kontekście biblijnym (np. u chronologicznie bliskiego Izajaszowi Ozeasza - por. Oz 2,20), jak i szerszym kontekście świata

6 Por. Wildberger, Isaiah 1-12, 463; Brzegowy, Ksiega Izajasza, 600. Obaj egzegeci zaznaczają jednak, że w. 10 ze swoją formułą „stanie się w owym dniu" wyróżnia się od poprzedzającego kontekstu zarówno pod względem czasowym, jak i tematycznym.

7 Por. Beuken, „The Emergence”, 97; Pikor, „Pytanie o mesjański sens”, 24.

8 Taką opinię wyrażają m.in.: Kaiser, Isaia. Capitoli 1-12, 332-333; Clements, „The Wolf Shall Live”, 89-91.

9 Por. Ma, Until the Spirit Comes, 35. 
semickiego ${ }^{10}$. Użycie motywów mitycznych wcale nie wyklucza Izajaszowego autorstwa w. 6-8. Prorok wykorzystuje to słownictwo do obwieszczenia całkowitego zwycięstwa sprawiedliwości nad złem ${ }^{11}$.

O mesjańskim charakterze proroctwa Iz 11,1-9 świadczy przede wszystkim kilka elementów. Po pierwsze, scharakteryzowanie występującego tam monarchy jako „odrośli z pnia Jessego" (w. 1), a nie odnoszenie się do Dawida, co ma wskazywać na absolutnie nową jakość oczekiwanego władcy. Po drugie, tożsamość nowego władcy jest ukazana przede wszystkim w jego relacji do YHWH, a nie w związku z obecną monarchią. Po trzecie, ostatecznym celem tegoż władcy będzie wprowadzenie nowej jakości życia wspólnoty poprzez odbudowanie złamanej relacji przymierza. Wreszcie, nowy Dawid obdarowany będzie boskimi kompetencjami ${ }^{12}$.

Struktura danego fragmentu przedstawia się następująco. Cztery części, składające się na Iz 11,1-9: w. 1-2 (A), w. 3-5 (B), w. 6-8 (B') i w. 9 (A'), tworzą układ chiastyczny ABB'A'. Zmiana podmiotu z „ducha YHWH” (w. 2) na władcę w w. 3 wyznacza początek drugiej części (w. 3-5). O jej jedności świadczą kryteria treściowe: terminologia sądownicza (sāpăạt, yākēăh,sedeq, mîsồr), a także słownictwo określające różne części ciała władcy. Odrębność trzeciej części (w. 6-8), będącej centrum naszego zainteresowania, wyznacza terminologia opisująca świat zwierzęcy. Ostatnia część (w. 9) wyróżnia się zmianą działającego podmiotu: choć nie jest bliżej dookreślony, to jednak tylko w tym wersecie występuje w 3 osobie liczby mnogiej. Paralelizm między częściami A i A’ wyznacza

10 Por. zebrane przez H. Wildbergera (Isaiah 1-12, 464-465) pozabiblijne obrazy pokojowej egzystencji w rajskim świecie.

11 Por. Wildberger, Isaiah 1-12, 481, 483. Charakterystycznym „śladem" obecności i autorskiej myśli Izajasza w proroctwie 11,6-8 jest umieszczenie tam osoby dziecka, co nie ma miejsca w podobnych poematach Bliskiego Wschodu.

12 Szczegółowe rozwinięcie tego problemu zob. Pikor, „Pytanie o mesjański sens", 26-34. 
przede wszystkim rzeczownik „poznanie”, a także podobna terminologia użyta na określenie jego udzielenia („spocząc" w w. 2 oraz „napełnić” i „wypełniać” w w. 9). Związek formalny między B i B' natomiast uwypukla występowanie obok siebie jednostek słabych i mocnych ze świata ludzi (B) i zwierząt $\left(\mathrm{B}^{\prime}\right)^{13}$.

\subsection{Relacje ekosystemu Iz 11,6-8}

W analizie urywka Iz 11,6-8 wiele miejsca poświęcono próbie uchwycenia znaczenia zwierząt w nim występujących. Dominują tu dwie główne tendencje. Pierwsza z nich to próba odnalezienia znaczenia dosłownego tegoż ekosystemu, według której Iz 11,6-8 wpisuje się w mit wiecznych powrotów. Istota odnowionego świata, w którym pokojowo egzystują zwierzęta i ludzie, polegałaby na przywróceniu na ziemi rajskich warunków z początków jej istnienia ${ }^{14}$. Druga grupa komentatorów skłania się do interpretacji alegorycznej, która może pójść co najmniej w dwóch różnych kierunkach. Pierwszy z nich jest uniwersalistyczny: występujące zwierzęta oznaczałyby poszczególne narody świata rozdarte konfliktami, które po interwencji nowego władcy mogą w końcu zażywać pokoju ${ }^{15}$. Z kolei drugie podejście jest ekskluzywne, zawężające perspektywę proroctwa tylko do samego Izraela ${ }^{16}$. W takim wypadku $11,6-8$ bytby obrazem

13 Szczegółowe omówienie struktury fragmentu Iz 11,1-9, za którym będziemy postępować w niniejszej pracy, jak również ukazanie dynamicznej zależności pomiędzy jego poszczególnymi częściami, zob. Pikor, Soteriologiczna metafora, 112-116.

14 Za taką interpretacją opowiada się np. Kaiser, Isaia. Capitoli 1-12, 339-340.

15 Por. Oswalt, The Book of Isaiah, 283. M. Buber suponowal, iż poszczególne zwierzęta mogą oznaczać konkretne narody, dziś już trudne lub nawet niemożliwe do identyfikacji. Por. Buber, Der Glaube der Propheten, 215.

16 Por. Tucker, „The Peaceable Kingdom”, 217-218. 
pogodzonych pokoleń izraelskich ${ }^{17}$ czy też pokoju pomiędzy poszczególnymi warstwami społecznymi wewnątrz narodu wybranego ${ }^{18}$. Aby odpowiedzieć na pytanie o sposób interpretacji owego mesjańskiego ekosystemu, dokonamy jego egzegezy głównie w oparciu o występujące czasowniki. Przekład tekstu przedstawia się następująco:

I zamieszka (wagār) wilk z barankiem, i leopard z koźlęciem spocznie (yirbāss), i cielę i lwiątko tuczyć się będą $(\text { yimrà } \hat{u})^{19}$ razem, i chłopiec będzie je prowadził (nohèg). I krowa i niedźwiedź paść się będą (tir'ênāh), razem będą spoczywać (yirbas su) ich młode, i lew jak wół będzie jadł $\left(y \bar{o}{ }^{\prime} k a l\right)$ słomę.

I bawić się będzie (waš̃ ăsă niemowlę nad norą węża, i nad kryjówkę żmii ${ }^{20}$ dziecko swoją rękę wyciągnie (hādāah) (11,6-8).

Analizowana część rozpoczyna się czasownikiem „zamieszkać” (w. 6a). Rdzeń ḡwr występuje często w Biblii

17 Por. Simian-Yofre, Testi isaiani, 48-49.

18 Por. Steck, „«... ein kleiner Knabe»”, 109-112; Blenkinsopp, Isaiah 1-39, 265; Kluczyński, „Motyw pokoju, 19.

19 Aparat krytyczny BHS proponuje, aby zamiast trzeciego zwierzęcia marî' („tuczone cielę”) czytać w tym miejscu yimra’û. Forma czasownikowa mārä nie jest poświadczona w Biblii, lecz występuje w językach ugaryckim i akadyjskim (HALOT, 630). Takie tłumaczenie potwierdzają

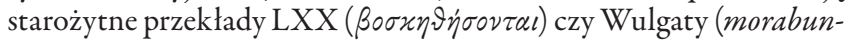
tur). Także paralelna konstrukcja w. 6-7 (wspólna czynność odnosząca się do par zwierząt) przemawia za przyjęciem wspomnianej poprawki.

20 Rzeczownik mà ùräh jest hapax legomenon. Niektórzy [np. Wildberger, Isaiah 1-12, 462; Stachowiak, Ksiegga Izajasza 1-39, 263] zakładając jego związek z akadyjskim mûru, proponują przekład „młoda żmija”. Zarówno tłumaczenia starożytnych przekładów wskazujące na „jamę”, „gniazdo”, jak i paralelne zestawienie mà ûrāh z ḅur („nora”) w w. 8 przemawiają za pozostaniem przy tłumaczeniu „kryjówka, jama”. 
Hebrajskiej ${ }^{21}$. Wyraża ideę zamieszkiwania w obcym kraju, wśród ludzi, którzy nie są z daną osobą spokrewnieni przez więzy krwi, co pociąga w konsekwencji brak co najmniej części praw i przywilejów rdzennych mieszkańców. Status takiego człowieka zależy najczęściej od gościnności gospodarzy, która na Bliskim Wschodzie zawsze odgrywała znaczącą rolę. Występowanie tego czasownika u Izajasza jest jednak rzadkie, gdyż prorok nie podnosi problemu przybyszów, którzy mogliby żyć wśród Izraela i doznawać ewentualnych przykrości ${ }^{22}$. Jedynym wyjątkiem jest Iz 16,4, gdzie prorok wzywa do udzielenia gościny uciekinierom z Moabu. Najbardziej znaczącym wydaje się jednak fragment Iz 5,17: „będą się pasły barany jak na swoim pastwisku i na ruinach spasieni przybysze (gàrîm) będą jedli". Cały fragment Iz 5,825 jest denuncjacją zachowań elit Izraela. Wielcy właściciele ziemscy w nieetyczny sposób pomnażają swoje bogactwa kosztem najbiedniejszych (w. 8$)^{23}$, a wymownym obrazem ich doczesnych uciech jest pijaństwo i obżarstwo (w. 11). Karząca interwencja YHWH odwraca sytuację: sprawia, że w kraju nie tylko zaczyna panować głód (w. 13) i braknie rodowitych mieszkańców-osadników (yôsēb-b_- w. 10), ale ich miejsce zajmują „spasieni obcy” (mēḅim gārîm - w. 17). W przywołanym kontekście interpretacja czasownika gār z 11,6a implikuje odczytanie w co najmniej jednym ze zwierząt alegorycznego obrazu innych narodów, które tym razem będą zamieszkiwać z Izraelem w pokoju. Nie będą jednak one u siebie, na swojej ziemi, co więcej, także naród wybrany nie może być

21 Ponad 80 wystąpień w formie czasownikowej, ponad 90 jako rzeczownik ger. Por. TDOT, II, 442.

22 Por. TDOT, II, 443, 447.

23 Szczegółowy opis problemu dotyczącego procesu latyfundyzacji i związanych z nim nadużyć zob. Davies, Prophecy and Ethics, 65-81. Co istotne, najczęściej proces bogacenia się poprzez przejmowanie majątków ziemskich ludzi mniej zamożnych nie był „niesprawiedliwy" w znaczeniu legalnym - wszelki proceder odbywał się zazwyczaj w świetle prawa i zgodnie z nim. 
tu rozpatrywany w kategoriach gospodarza. Wymownie świadczy o tym podsumowujący w. 9 stwierdzający prawo własności YHWH do danego terenu (góry). W ten nurt wpisuje się Iz 2,1-5, gdzie centralnym miejscem jest góra świątyni YHWH, do której nadciągną narody (w. 2) i będą przebywać tam w pokoju (w. 4). Owo miejsce zgromadzenia ludów jest ewidentną własnością Boga (w. 3), zatem zarówno Izrael jak i inne narody są tam „przybyszami”.

Czasownik rabas jest użyty dwukrotnie w analizowanej części (w. 6b.7b). Pierwotne jego znaczenie to „leżeć”, jednak znów u Izajasza nie chodzi wyłącznie o pozycję horyzontalną człowieka czy zwierzęcia. W wyroczni przeciw Babilonowi z Iz 13 występuje dwukrotnie (w. 20.21), uwypuklając na zasadzie kontrastu zniszczenie miasta. Z jednej strony zostanie ono wysiedlone i nie będzie nigdy więcej zamieszkiwane, nie będą się tam zatrzymywać (lo’ yarbịs $\hat{u}$ ) nawet pasterze (ro' im) czy wędrowni Arabowie (w. 20). Z drugiej strony nieodwołalność zniszczenia przypieczętowana zostaje uwaga o przebywaniu (wərābassî) w opuszczonych domach dzikich zwierząt (w. 21). Izajasz chętnie zestawia ze sobą rdzenie rbs i $r$ ' $h$, czy to w kontekście opieki YHWH nad Jego wybrany$\mathrm{mi}(14,30)$, czy to ukazując obraz spustoszenia $(27,10$, por. 5,17). Także w analizowanej części zestawione są ze sobą paralelnie czasowniki "paść się" (tir'ênāh) w odniesieniu do krowy i niedźwiedzicy (w. 7a) oraz „leżeć, spoczywać” (yirbạs $\hat{u}$ ) w odniesieniu do ich młodych (w. 7b). Powiązanie rdzenia rbs ze światem pasterskim jest też widoczne w innych tekstach Biblii Hebrajskiej (por. Rdz 29,2; Jr 33,12; 50,6). W tym kontekście należy zwrócić uwagę na fragmenty, w których to YHWH jest przedstawiony jako pasterz prowadzący swój lud (rō' $\hat{\imath}$ - „mój pasterz” w Ps 23,1, czy 'er'eh - „ja będę pasł" moje owce w Ez 34,14.15), gdyż tylko On jest w stanie zapewnić prawdziwy odpoczynek swojemu ludowi (yarbị̂sēnî - „sprawia, że mogę leżeć” w Ps 23,2, czy tirbasanāh - „będą się pasły” na dobrym pastwisku w Ez 34,14). Czasownik rābas, używany w kontekście pasterskim na określenie ocze- 
kiwanego stanu pokoju, implikuje zatem istnienie osoby pasterza będącego gwarantem tego pokoju. W opisie mesjańskiego ekosystemu Iz 11,6-8 to spostrzeżenie potwierdza zestawienie przez Izajasza czasowników rābas i rāāh.

W analizowanej części występują dwa czasowniki odnoszące się do spożywania pokarmu. Pierwszy z nich - yimra' $\hat{u}$ (w. 6c) - pochodzi od tego samego rdzenia co rzeczownik marî̀, który na kartach Biblii oznacza tuczone cielę, najczęściej składane na ofiarę (por. 2 Sm 6,13; $1 \mathrm{Krl}$ 1,9). Choć u Izajasza $(1,11)$ czy Amosa $(5,22)$ akt składania takich ofiar jest denuncjowany, dzieje się to jednak ze względu na dyspozycje moralne ofiarodawców, którzy w tym samym czasie pełnienia kultu uciskają ubogich ludu. Pod względem legalnym takie zwierzę musiało być bez skazy (por. Kpł 1,3.10; 3,1.6) i pierwszej jakości. Stąd obraz Iz 11,6c ma wydźwięk absolutnie pozytywny, związany ściśle z obfitością pokarmu, jakiego doświadczają zwierzęta w swoim środowisku. Nie chodzi tu o ilość mającą zapewnić tylko przeżycie, ale o obfitość pozwalającą na prosperowanie ponad przeciętny stan. Drugi z czasowników - yo'kal (w. 7c) nabiera u Proto-Izajasza specyficznego zabarwienia, występuje bardzo często w proroctwach związanych z sądem YHWH i Jego karzącą interwencją. Jego użycie rozwija się w dwóch kierunkach. Pierwszy ma wymiar pozytywny: bycie posłusznym YHWH i sprawiedliwym wobec ludzi prowadzi do obfitowania, do ,zażywania” dóbr ziemskich $(1,19)$, czyli owocu swojej pracy $(3,10)$. Jest to powrót do sytuacji sprzed aktu nieposłuszeństwa pierwszych rodziców, które skutkowało niewystarczającą jakością pracy człowieka, która nie zapewniała mu właściwego utrzymania (por. Rdz 3,17-19). Podobną myśl znajdujemy w Iz 30, w którym odrzucenie bożków i przyjęcie YHWH (w. 22) sprawia deszcz, a tym samym urodzaj zbiorów. Chleb, który zostanie wypieczony z zasianego zboża, staje się już nie tylko gwarantem przeżycia, ale zapewnia egzystencję dostatnią, gdyż będzie soczysty i pożywny (w. 23a), a obraz owego dostatku uzupełniony jest o pasącą się na rozległych pastwiskach trzodę (w. 23b). W końcu „spożywanie” śmietany i miodu jest zna- 
kiem nadejścia czasów mesjańskich (7,15.22). Drugi kierunek, ku któremu w Proto-Izajaszu zmierza użycie 'ākal, ma wymiar pejoratywny i związany jest z karzącą interwencją YHWH. Opór i krnąbrność sprawia, że to sam lud zostanie „pożarty” mieczem $(1,20)$, który metaforycznie oznacza inne narody $(9,11)$, i wyniszczony tak, jak ogień pochłania ('ékoōl) słomę (5,24).

Obraz chłopca w w. 6d, który prowadzi (nohèg) cielę i lwiątko, w pisuje się w tradycję pasterską przywołaną wystąpieniami czasowników rābas i rāàh. W znaczeniu pierwotnym czasownik nāhag ma człowieka jako podmiot, a zwierzę jako dopełnienie czynności, i oznacza prowadzenie stada na pastwisko (por. Rdz 31,18; Wj 3,1). Taką czynność wykonuje też sam YHWH, który prowadzi Izraela, tak jak pasterz swoje stado (por. Ps 80,2). Znaczenie pejoratywne odnosi się przede wszystkim do uprowadzenia do niewoli (por. $\mathrm{Rdz}$ 31,26; $1 \mathrm{Sm} 30,2$; Iz 20,4) ${ }^{24}$. Czasownik nāhağ oznacza zatem zawsze podporządkowanie, które może mieć dwojaki charakter: albo opiekuńczy, albo niewolniczy. Czynność prowadzenia, przywołująca obraz życia pasterskiego, dotyczy zatem przywódców ludu, którzy ustanowieni są do kierowania i opieki nad powierzonymi im ludźmi (por. Iz 60,11).

Kolejnym czasownikiem opisującym czynność dziecka (yônēq), jest säa’. Jego znaczenie w Pilpel to „bawić się”, ,rozkoszować", potwierdzone w tej koniugacji jeszcze w Ps 119,70, gdzie przyczyną rozkoszy jest prawo YHWH (por. Ps 94,19 oraz Ps 119,16.47 w Hitpalpel, wszystkie z nich nawiązują do obecności YHWH). Obraz niemowlęcia bawiącego się zatem na norze kobry nie tylko nawiązuje do pokojowej koegzystencji z jadowitym zwierzęciem czy nawet do pierwotnego porządku rajskiego, zburzonego przecież interwencją właśnie wężza ${ }^{25}$, ale semantycznie budzi skojarzenie radości i pociechy spowodowanej bliskością samego YHWH, przestrzeganiem

24 Por. TDOT, IX, 258.

25 Por. Nwaoru, „Building a New World”, 140; Brzegowy, Ksiega Izajasza. Rozdziaty 1-12, 619. 
Jego prawa (tôrāh - Ps 119,70), przykazań (mịswāh - Ps 119,47) i ustaw (buqqāh - Ps 119,16).

Ostatni z czasowników, odnoszący się do postaci ludzkich ( $h \bar{a} \underline{d} \bar{a} h-$ w. 8), jest zgodnie interpretowany jako gest wyciągnięcia ręki $\mathrm{i}^{26} \mathrm{ku}$ miejscu niebezpiecznemu, jakim jest kryjówka gada. Choć użyty tu czasownik występuje tylko raz w TM, w kontekście Proto-Izajasza znów budzi określone skojarzenia. W pierwszym rzędzie odnosi czytelnika do wydarzenia wyjścia z niewoli egipskiej i wyciągnięcia ręki przez Mojżesza (por. Wj 14,26). Ten gest będzie później kilkukrotnie podjęty przez proroka. Pierwszy raz dostrzegamy go u Asyrii, która, stojąc pod murami Jerozolimy, potrząsa ręką w złowrogim geście groźby po marszu Sargona w 720 r. przed Chr. (por. Iz 10,32) ${ }^{27}$. Później jednak ta czynność przynależy już tylko YHWH. W Iz 11,15 Pan „potrząśnie ręką (hēnîp yādố) na Rzekę"i i sprowadzi resztę swojego ludu z Egiptu i Asyrii. Znak groźby dla przeciwników jest jednocześnie znakiem opieki dla narodu wybranego: gdy Egipcjanie będą drżeć na widok ręki YHWH (por. 19,16), dla Izraela będzie ona gwarancją bezpieczeństwa.

Przeprowadzona analiza czasowników pozwala podzielić wspomnianą część Iz 11,6-8 na dwa urywki: w. 6 i w. 7-8. W każdym z nich można wyodrębnić trzy cechy opisujące eschatologiczny pokój, a mianowicie: wspólne zamieszkiwanie (pasienie się) zwierząt, spożywanie pokarmu dostępnego w obfitości oraz prowadzenie przez dziecko. Motyw wspólnego zamieszkiwania zwierząt określony jest czasownikami gûur, rābạs i rāāăh, które u Izajasza są używane przede wszystkim w kontekście pasterskim, metaforycznie oddającym

26 Także arabskie hada', podobnie jak analizowany wcześniej czasownik nāhag, oznacza "prowadzić”, „kierować”. Por. BDB, 213.

27 Za takim umieszczeniem w czasie kampanii Iz 10,27-34 opowiada się większość komentatorów, argumentując to brakiem wzmianki o zajęciu Mispa oraz o obleganiu Jerozolimy. Por. Sweeney, „Sargon’s Threat", 464-466; Blenkinsopp, Isaiah 1-39, 260-261; Brzegowy, Ksiega Izajasza. Rozdziaty 1-12, 561-562. 
rzeczywistość eschatologiczną. Jak pokazaliśmy, skutkiem panowania nowego władcy będzie nie tylko koegzystencja pokoleń izraelskich (gdyż to przede wszystkim dla nich jest ustanowiony nowy władca, którego brak tak dobitnie jest ukazywany przez Izajasza w sekcji 1-12), ale też i innych narodów na miejscu odpoczynku. Nie będzie to jednak ziemia żadnego z owych narodów, ani nawet Izraela, ale góra rozpoznana przez nie jako własność YHWH (w. 9a, por. Iz 2,2-4). Pokojowe zamieszkiwanie na określonym terytorium jest elementem koniecznym, ale niewystarczającym do urzeczywistnienia owego eschatologicznego ekosystemu. Drugi konieczny warunek to obfitość pokarmu reprezentowana przez czasowniki mārā' i 'ák kal. Zadaniem nowego władcy, zwłaszcza wobec biednych i ubogich ziemi $(11,4)$, będą takie sądy, które zapewnią dostatek pożywienia. Nie chodzi tu jednak o zaspokojenie fizycznego głodu. Człowiek spożywa z owocu swoich uczynków $(3,10)$. Obfitość bogactwa i siły militarnej $(2,7)$ wcale nie jest gwarantem pokoju, przeciwnie, nawet tak uzbrojony lud mogą „pożreć” jego przeciwnicy $(9,11)$. Dopiero obfitowanie w poznanie YHWH $(11,9)$, które można odnaleźć w Jego przykazaniach, sprawia prawdziwy pokój $(48,18)$. W końcu ostatnim elementem nowego ekosystemu pokoju jest sam fakt istnienia nowego monarchy i sprawowania przez niego władzy, na co wska-

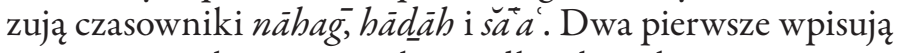
się w terminologię pasterską, podkreślając bezpieczeństwo i prowadzenie ludu przez nowego władcę. Nie można zatem mówić, iż jedyną funkcją występujących w Iz 11,6-8 postaci ludzkich jest wpisanie się w harmonijny obraz przyrody reprezentowanej przez koegzystujące w pokoju zwierzęta dzikie i domowe. Zarówno wcześniejsze proroctwa o nowym władcy, przedstawiające go jako dziecko (Iz 7,10-17; 8,23b-9,6), jak i egzegeza tekstu Iz 11,6-8 jasno pokazują, iż gwarantem nowego, doskonałego pokoju jest pojawienie się władcy według woli YHWH. Jego ścisły związek z Bogiem poprzez przestrzeganie prawa i sprawiedliwości pośrednio impliku- 
je ostatni z czasowników $\breve{s a} a `$ wskazujący na przestrzeganie Bożych ustaw, które są rozkoszą dla podniebienia (Ps 119,70).

\section{Próba odczytania Iz 11 w św ietle Iz 32}

Jako uzupełnienie wniosków płynących z egzegezy Iz 11,6-8 zostanie przedstawiona krótka analiza dwóch stychów z Iz 32, mianowicie w. 2 i w. 17. Badania nad strukturą Księgi ProtoIzajasza ukazują wzajemną zależność rozdz. 1-12 oraz 28-33. Analogię wspomnianych sekcji przedstawia się w kontekście licznych związków semantycznych, podobieństw strukturalnych rozdziałów, przenikania się w nich wspólnych motywów (np. sądu i zbawienia) czy rozwijania poszczególnych idei z sekcji 1-12 w rozdz. 28-33 (np. motyw „styszenia dla głuchych" i „widzenia dla ślepych”) ${ }^{28}$. Zasadne jest zatem postawienie pytania o istnienie wykoncypowanych cech mesjańskiego ekosystemu Iz 11,6-8 w sekcji rozdz. 28-33, a zwłaszcza w rozdz. $32^{29}$.

\subsection{Skutki sprawiedliwego panowania według Iz 32,2}

Iz 32,2 w następujący sposób określa nowych władców: „I każdy będzie jak schronienie przed wiatrem, osłona przed ulewą; jak kanały wody na wyschniętym miejscu; jak cień potężnej skały na spieczonej ziemi”. Podmiot wersetu kryje się za słowem

28 G. Stansell używa wobec wspomnianych sekcji terminu „funkcjonalny dublet", zaznaczając, iż nie chodzi o zwykłe powtórzenia pewnych myśli, lecz o dający się zauważyć rozwój i reinterpretację tekstów. Por. Stansell, „Isaiah: 28-33”, 99.

29 G. Stansell nie mówi wprost o odpowiedniości rozdz. 11 i 32. Wskazuje jednak na podobieństwo 12,1-6 do 33,2-24, przede wszystkim przez ich hymniczno-liturgiczny charakter. To może sugerować pewne podobieństwo rozdz. 11 i 32, zwłaszcza gdy rozważymy ich charakter konkludujący dla poprzedzających sekcji. Egzegeta nie rozwija jednak szczegółowo tej hipotezy. Por. Stansell, „Isaiah 32”, 6; Stansell, „Isaiah: 28-33”, 79 . 
„każdy”, jednak bliższe przyjrzenie się kontekstowi wypowiedzi jednoznacznie identyfikuje go ze wspomnianymi w w. 1 królem i książętami. Problem kryzysu władców Jerozolimy jest jednym z kluczowych dla Izajasza, zwłaszcza dla sekcji Iz $1-12$. Zarysowany już w 3,1-15 obraz przedstawia sytuację zepsucia elit, co potwierdzone jest dalej w 5,8-30 czy 9,7-10,4. Jednocześnie zarysowuje się nadzieja naprawienia tej sytuacji, co widać wyraźnie w proroctwach o Emmanuelu z rozdz. 7 i o nowym potomku królewskim z rozdz. 9 i 11. Początek rozdz. 32 wpisuje się zatem w nurt oczekiwań sprawiedliwego władcy dla Izraela. Iz 32,2 będziemy traktowali jako tryptyk metaforyczny, którego poszczególne części omówimy ${ }^{30}$.

Pierwsza metafora, składająca się z dwóch części, przywołuje obraz ochrony przed złymi warunkami pogodowymi. Zwraca ona jednak uwagę nie na charakter owej ochrony, a na czyhające zagrożenia. Pierwsze z nich jest określone terminem $r \hat{u}^{a} b$ oznaczającym w kontekście Izajasza wiatr o dużej sile. Ma on znaczenie symboliczne: odnosi się do tchnienia YHWH, który okazuje swoją moc wobec narodów $(11,15 ; 17,3)$, a także do zagrożenia, jakie obce potęgi stwarzają wobec Judy (np. wojska syro-efraimskie w 7,2 czy asyryjskie w 32,2 ). Także drugi termin zerem, oznaczający gwałtowną ulewę, nawałnicę, pojawia się jako symboliczny obraz sił będących zagrożeniem narodu wybranego $(25,4 ; 28,2)$. Istota wspomnianych porównań leży zatem w ukazaniu roli króla i książąt: są oni nie tyle ochroną przed złymi warunkami pogodowymi, lecz przed wrogimi narodami czy grupami ludzi. Analogiczne przesłanie w Iz 11,6-8 ukazane zostało nie tylko przez alegoryczne zestawienie zwierząt dzikich i domowych oraz osoby dziecka, ale przez wyeksponowanie charakteru ich wzajemnych relacji: wspólnego zamieszkiwania w pokoju oraz istnienia władcy będącego gwarantem takiego stanu rzeczy.

30 Szczegółowy opis wspomnianej metafory, za którym będziemy podążali, jak i dwóch kolejnych porównań został zaczerpnięty z: Pikor, Soteriologiczna metafora, 202-205. 
Ciekawa jest interpretacja drugiego porównania: ,jak kanały wody na wyschniętym miejscu". Występująca w tym miejscu syntagma palgề-mayim oznacza sztuczne kanały służące do irygacji terenu, który sam z siebie jest ziemią żyzną i mógłby być uprawiany, lecz brakuje mu właśnie nawodnienia. Nawiązanie do Iz 11,6-8 może iść w dwóch kierunkach. Po pierwsze, podejmuje temat żyzności terenu. Przy właściwej dyspozycji rządzących, odczytujących swoją misję jako narzędzie w ręku Boga (oni są tylko kanałem, przez które woda jest doprowadzana), ziemia w obfitości wydaje swoje owoce. Jednocześnie to nie władcy, ale sam Bóg jest ostateczną przyczyną, dzięki której taki pokój i dobrobyt następuje, On sam uprawia i przygotowuje ziemię, na której w przyszłości znajdzie schronienie Izrael (por. Ps 65,10). Po drugie natomiast, kanały nawadniające Biblia Hebrajska wykorzystuje jako symbol Tory, która „medytowana przez człowieka, czyni go podobnym do drzewa zasadzonego nad «kanałami wody»" ${ }^{31}$, którego liście nie więdną (Ps 1,3). Rozważane ustawy i prawo YHWH są zatem pokarmem dla człowieka, który sprawia jego prawidłowy wzrost, co więcej, pokarmem będącym rozkoszą dla podniebienia (por. Ps 1,2). Obraz ten wpisuje się w ekosystem pokoju z Iz 11,6-8, w którym zauważamy zarówno obfitość dostępnego pokarmu (czasowniki yimra' û i yo'kal), a także fakt rozkoszowania się takim stanem (czasownik š̌ ăsă ). To właśnie prawo YHWH okazuje się prawdziwym pokarmem człowieka, pożywnym i przynoszącym rozkosz, a jego „spożywanie” prowadzi do wypełnienia ziemi „znajomością” YHWH (Iz 11,9).

Przy analizie drugiego porównania należy zauważyć jeszcze jedno podobieństwo rozdz. 11 i 32. Dar ducha YHWH zostaje udzielony nowemu władcy $(11,2)$, przez co może skutecznie administrować sprawiedliwością $(11,4.5)$ i w ten sposób zaprowadzić oczekiwany pokój (11,6-8). Proroctwo mesjańskie z Iz 11 w pisuje się w nurt oczekiwań na sprawied-

31 Pikor, Soteriologiczna metafora, 203. 
liwego władcę, niemniej wnosi w porównaniu do poprzednich (Iz 7,10-17; 8,23b-9,6) pewną nowość: dar ducha YHWH zostaje udzielony nie tylko nowemu władcy, ale całej wspólnocie ${ }^{32}$. Świadczy o tym przede wszystkim w. 9, w którym jest mowa o napełnieniu kraju znajomością YHWH ${ }^{33}$. Ta myśl zostaje rozwinięta i dopełniona w Iz 32. Choć pierwszymi, na których spoczywa obowiązek administrowania prawem i sprawiedliwością, są król i książęta (w. 1) i to oni mają zapewniać swojemu ludowi bezpieczeństwo (w. 2), to jednak ich funkcja jest pośrednicząca: są „kanałami”, przez które dar ducha YHWH zostanie udzielony całej społeczności (w. 15). Dzięki temu darowi nastąpi przemiana wspólnoty: już nie tylko jej przywódcy, ale i cały lud będzie postępował według prawa i sprawiedliwości, co zaowocuje pokojem dającym prawdziwe szczęście (w. 20). W obu proroctwach ostatecznym dawcą pokoju pozostaje zawsze YHWH.

Trzecia metafora analizowanego w. 2: „jak cień potężnej skały na spieczonej ziemi ('erẹs ăyēēāh)", znów podkreśla zadanie władcy, jakim jest ochrona powierzonych mu poddanych. Ten sam przymiotnik 'àyēp'znajdujemy także w Iz 28,12 na określenie ludu, który jest zmęczony i wyczerpany (podobne znaczenie w Sdz 4,21; 8,4; Jr 4,31). Ten znużony ciągłą wojną z Asyrią naród potrzebuje odpoczynku (mənuhāh $-28,12)$, który zostanie mu udzielony jako owoc daru ducha z wysokości. Bycie ,jak cień potężnej skały” natomiast odnosi czytelnika w pierwszym rzędzie do YHWH, który jest „cieniem” - ochroną dla swojego ludu (Iz 4,2), w dalszej perspektywie oznacza także szukanie bezpieczeństwa u ziemskich władców (Iz 30,2-3) ${ }^{34}$. Wspomniana metafora oznacza

32 Por. Ma, Until the Spirit Comes, 101.

33 Ponadto wspomnianego obrazu powszechności owego daru dopełnia metafora akwatyczna „na kształt wód, które napełniają morze”. Szczegółowy opis owej metafory jak i rozumienia syntagmy „poznanie YHWH" zob. w: Pikor, Soteriologiczna metafora, 122-125.

34 Przyrównywanie swojej roli do cienia dającego odpoczynek było chętnie stosowane przez władców także w świecie pozabiblijnym - tak 
zatem zapewnienie ludowi pokoju, który będzie nie tylko brakiem wojny, ale także wytchnieniem po trudach i poczuciem rzeczywistego bezpieczeństwa. Zatem także ów trzeci obraz wpisuje się w relacje ekosystemu Iz 11,6-8. Gest wyciągniętej ręki dziecka nad norą węża przywodzi na myśl gest protekcji tym bardziej, iż postaci ludzkie z Iz 11,6-8 antycypują oczekiwanego, doskonałego władcę, tak często przywoływanego w sekcji Iz 1-12 także w osobie dziecka (Iz 7,10-17; 8,23b-9,6). Wspólny jest również motyw bezpieczeństwa i odpoczynku, symbolicznie oddane przez występowanie zwierząt pasących się razem bez lęku, z zapewnioną obfitością pokarmu.

Analizowany w. 2 przynosi wyraźne ukazanie skutków władzy sprawowanej przez oczekiwanego, doskonałego monarchę. W. Pikor streszcza je w trzech punktach ${ }^{35}$ : ochrona ludu przed zagrożeniami z zewnątrz, zapewnienie wspólnocie życia oraz stworzenie warunków do pomyślnego rozwoju. Nadużyciem byłoby poszukiwanie ścisłej odpowiedniości wspomnianych trzech aspektów z trzema cechami pokoju, jaki będzie panować w mesjańskim ekosystemie z Iz 11,6-8. Niemniej jednak wykoncypowany wcześniej opis przyszłego stanu pokoju między zwierzętami całościowo zawiera się w opisie zawartym w Iz 32,2, posiadają one również ten sam element metaforyzowany (pokój), choć przedstawiony przez elementy metaforyzujące należące do różnych dziedzin (świat zwierząt i świat przyrody nieożywionej).

\subsection{Istota nowego porządku według Iz 32,17}

Komentatorzy bardzo często używają do opisu stanu przyrody z Iz 11,6-8 słowa „pokój”, choć w całym rozdz. 11 takie słowo nie pada. Oczywiście owa intuicja jest jak najbardziej

określają siebie np. Lipit-Isztar czy Hammurabi. Por. Wildberger, Isaiah 28-39, 237-238; Brzegowy, Ksiega Izajasza. Rozdziaty 13-39, 626.

35 Obszerne podsumowanie owych metafor w: Pikor, Soteriologiczna metafora, 205. 
poprawna. Czy można jednak uzasadnić ją na podstawie tekstów Izajasza, a także uściślić charakter owego pokoju? Z pomocą przychodzi nam znów spojrzenie na Iz 32, w którym w w. 17 padają trzy konkretne określenia stanu panującego w przemienionej wspólnocie. Będą to: pokój (sălôm), spokój (has̆qẹt) i bezpieczeństwo (bẹtah). Wszystkie one są przedstawione jako pochodna zaistnienia sprawiedliwości -.sodāqāh.

Termin sălôm nie należy do charakterystycznego słownictwa Proto-Izajasza ${ }^{36}$, powinno się go odczytywać przede wszystkim w kontekście Iz 9 zapowiadającego rządy nowego, sprawiedliwego władcy. Wśród czterech tytułów królewskich zawartych w Iz 9,5 tylko ostatni - śar sălôm - ma wymiar ziemski, pozostałe trzy mają w swoim wydźwięku zawsze odniesienie do YHWH. Co charakterystyczne, Izajasz, mówiąc o utwierdzeniu królestwa prawem i sprawiedliwością $(9,6)$, nie używa w odniesieniu do nowego władcy słowa melek - król, zaznaczając tỵm samym, iż jedynym władcą jest YHWH. Użyty tytuł sar zamiast melek wskazuje na podporządkowanie i relację poddaństwa wobec jedynego króla YHWH ${ }^{37}$. Zatem zasiadający na tronie Dawida $(9,6)$ nie jest dawcą pokoju, lecz jego administratorem. Wpisuje się to w myśl, iż wszystkie cztery imiona mają charakter funkcjonalny, tzn. nie tyle identyfikują osobę nowego władcy, ale za jej pomocą objawiają sposób i charakter obecności Boga w historii człowieka ${ }^{38}$. Jeśli każde z imion dotyka różnych sfer działalności monarchy ${ }^{39}$, to egzemplifikacją działalności śar sălôm byłby właśnie obraz ekosystemu Iz 11,6-8. Komplementarność opi-

36 Beuken, Isaiah II, 235.

37 O podporządkowaniu śar wobec króla mówią m.in. Rdz 12,15; 39,1; Lb 22,13; Jr 25,19.

38 Por. Beuken, Jesaja 1-12, 251.

39 „Bóg mocny” podnosiłby aspekt relacji króla z Bogiem, „Ojciec na wieki” - z poddanymi, „Twórca przedziwnych planów” wskazywałby na umiejętność realizacji Bożych zamiarów, „Książę pokoju” natomiast - na rzeczywiste rezultaty sprawowanej władzy. Por. Pikor, „Pytanie o mesjański sens”, 21. 
sów doskonałej monarchii z rozdz. 9, 11 i 32 podkreśla także konsekutywność przemian w niej zachodzących. Pokój nie będzie bezpośrednim owocem działalności nowego władcy. We wspólnocie rozdartej przemocą zaprowadzi on najpierw prawo i sprawiedliwość, a następnie one zaowocują prawdziwym pokojem $(9,6 ; 11,5-6 ; 32,17)$. Idea pokoju sălôm według Izajasza jest zatem nierozłącznie związana z istnieniem osoby-pośrednika, który ten pokój zaprowadzi, a który jednocześnie pozostaje w ścisłej relacji z Bogiem. Wpisuje się to w obraz Iz 11,6-8. Istnienie sprawiedliwego władcy sygnalizują postaci ludzkie w mesjańskim ekosystemie. Jednak dziecko nie tylko prowadzi wspólnotę (czasowniki nāhag i hādāhb), ale będzie „bawić się" na norze węża (w. 8). Prawdziwym powodem, dla którego można zażywać owej dziecięcej rozkoszy i beztroski, jest zawsze prawo YHWH i jego przestrzeganie (Ps 119,70). W Iz 11,6-8 pośrednio widać zatem także związek nowego władcy z Bogiem ${ }^{40}$, związek, którego istotą jest podporządkowanie się Bożym ustawom.

Tak jak rzeczownik sălôm zakłada u Izajasza istnienie władcy, który pokój zaprowadzi, tak dwa kolejne terminy z Iz 32,17 wskazują już na bezpośrednią relację zarówno liderów, jak i całej wspólnoty do Boga. Stan nowego porządku opisuje sło-

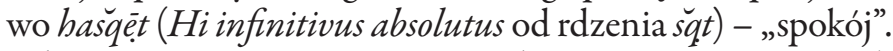
Rdzeń ten pierwotnie wyraża stan bycia nieporuszonym, jak np. nieporuszona i spokojna może być powierzchnia morza (por. Iz 57,20; Jr 49,23). Jego użycie jest związane z oczekiwaniami pokoju i bezpieczeństwa w ziemi obiecanej, co wyraźnie widać w regularnych opisach pokoju z Księgi Sędziów ( $\mathrm{Sdz} 3,11.30 ; 5,31 ; 8,28)$. W kontekście Izajasza znamienne są dwa fragmenty, oba podkreślają, iż prawdziwym dawcą pokoju jest YHWH, gdy pokłada się w Nim ufność. W kon-

40 Bezpośrednio tę obserwację natomiast potwierdza struktura fragmentu Iz 11,1-9, gdzie w paralelnej do w. 6-8 w części w. 3-5 wskazane jest „upodobanie” władcy w bojaźni YHWH (w. 3) oraz jego postępowanie według sprawiedliwości (w. 4-5). 
tekście wojny syro-efraimskiej do zachowania „spokoju” wezwany jest władca - król Achaz $(7,4)$. Ta jego postawa ma charakteryzować się nie tylko nieskłanianiem się ku żadnej ze stron konfliktu (Asyrii lub koalicji), ale przede wszystkim pokładaniem ufności w Bogu. Król Achaz na pewno pragnie bezpieczeństwa dla swojego ludu, bezpośrednie zagrożenie wojną $(7,1.6)$ rodzi w nim jednak lęk $(7,2)$, co potwierdza, iż to nie ziemski władca jest źródłem pokoju. Niemniej jednak Achaz ma już swój własny plan ratowania pokoju i obrony przed koalicją antyasyryjską, dlatego też nie chce prosić o znak od Boga dla siebie (7,10-14). Pozostanie „spokojnym” oznacza zatem położenie całej swojej ufności $(7,4)$ w YHWH, co w konsekwencji prowadzi do ocalenia. Powyższe obserwacje potwierdza drugi obraz z Iz 30,15, w którym sam YHWH wskazuje źródło siły i ratunku. Nie są nimi szybkie konie i wozy do ucieczki $(30,16)$, ale właśnie spokój i ufność pokładane w YHWH, które winny charakteryzować postawę nawrócenia całego Izraela $(30,15)^{41}$. Pokój według Izajasza jest zatem nierozłącznie związany z osobistą relacją rządzących i całego ludu z Bogiem.

Ze wspomnianym terminem hašqẹt ściśle związane jest trzecie określenie bezpieczeństwa - bẹtạ. Izajasz stosuje je przede wszystkim dla wskazania właściwej relacji człowieka do Boga, czyniąc to na dwa sposoby. Pierwszy to bezpośrednie wezwanie do pokładania ufności - beta np. w Iz 12,2; 26,4. Drugi jest pośredni i polega na ukazaniu skutków poszukiwania bezpieczeństwa poza Nim. Budowanie pokoju na krzywdzie i zdradzie $(30,12)$ czy poszukiwanie go w dziełach rąk ludzkich (np. w egipskich rydwanach w Iz 31,1, por. 36,6$)$ lub w samym sobie $(32,10.11)$ jest nieskuteczne i zawsze prowadzi do upadku ${ }^{42}$. Izrael żył nadzieją, że w przyszłości nadejdzie okres życia w bezpieczeństwie (por. Kpł 25,18.19; 26,5; Pwt 12,10; Jr 32,37; Ez 28,26; 34,25; 38,8.11;

42 Por. Beuken, Isaiah II., 235. 
Za 14,11), jednak, pragnąc tę nadzieję urzeczywistnić, niejednokrotnie wybierał ku jej realizacji złą drogę: ufności nie w Bogu, lecz w sile człowieka. Choć zaprezentowana idea pokoju związana z terminami hašqẹt $i$ bẹta h nie jest ukazana wprost w Iz 11,6-8, odnajdziemy tam jednak pośrednio jej istnienie. Relacja całej wspólnoty do Boga oddana jest przez czasowniki mâră' i 'ākeal odnoszące się do zwierząt. Obfitość pokarmu, jak zaznaczyliśmy, nie oznacza tylko zaspokojenia fizycznego głodu, lecz odnosi czytelnika do idei obfitowania w sprawiedliwość, zarówno w sferze intelektualnej (poznanie prawa YHWH), jak i behawioralnej. Podporządkowanie YHWH i Jego nakazom, oraz - co za tym idzie - również pokładanie w Nim ufności, implikują także czasowniki rābạs i rā'āh, które budzą skojarzenia z Bogiem jako pasterzem swojego ludu, u Izajasza najczęściej w perspektywie przyszłego, oczekiwanego pokoju.

\section{Podsumowanie}

Dotychczasowe analizy fragmentu Iz 11,6-8 były skoncentrowane głównie na opisie i odczytywaniu roli występujących w nim zwierząt i postaci ludzkich, włączając w to różne płaszczyzny symboliczne. Jednakże istota każdego ekosystemu tkwi nie tylko w opisie gatunków i rodzajów, ale także ich wzajemnych relacji i relacji do środowiska - taka jest definicja ekologii. W artykule została podjęta próba uzupełnienia wspomnianych analiz Iz 11,6-8 o opis zachowań zwierząt i ludzi, co pozwoliło uchwycić trzy główne cechy mesjańskiego ekosystemu pokoju. Po pierwsze, wspólne pasienie się zwierząt na polach będących własnością YHWH. Po drugie, spożywanie pokarmu dostępnego w obfitości, co symbolicznie wskazuje na medytowanie i przestrzeganie Bożego prawa. Wreszcie, prowadzenie wspólnoty przez władcę według woli YHWH. Rozumienie przez proroka stanu pokoju i bezpieczeństwa zostało uzupełnione obrazami z innych części Proto-Izajasza, 
zwłaszcza z Iz 32, którego fragmenty w powyższym świetle jawić się mogą jako „odpowiednik” Iz 11 uzupełniający i pogę̨biający treści w nim zawarte.

\section{BIBLIOGRAFIA}

Alonso Schökel L. - Sicre Diaz, J.L., I Profeti (Commenti Biblici; Roma: Borla ${ }^{3}$ 1996).

Beuken W.A.M., Isaiah II. Chapters 28-39 (HCOT; Leuven: Peeters 2000).

Beuken W.A.M., Jesaja 1-12 (HThKAT; Freiburg - Basel - Wien: Herder Verlag 2003).

Beuken W.A.M., „The Emergence of the Shoot of Jesse: An

Eschatological or a Now Event?", Calvin Theological Journal 39 (2004) 88-108.

Blenkinsopp J., Isaiah 1-39. A New Translation with Introduction and Commentary (AB 19; New Haven, CT - London: Doubleday 2000).

Brzegowy T., Księga Izajasza. Rozdziaty 1-12. Wstęp-przektad z oryginatu - komentarz (NKB.ST 22/1; Częstochowa: Edycja Świętego Pawła 2010).

Brzegowy T., Ksiega Izajasza. Rozdziaty 13-39. Wstęp-przektad z oryginatu - komentarz (NKB.ST 22/2; Częstochowa: Edycja Świętego Pawła 2014).

Buber M., Der Glaube der Propheten (Zürich: Manesse Verlag 1950). Clements R.E., „The Wolf Shall Live with the Lamb: Reading Isiaiah 11:6-9 Today", New Heaven and New Earth. Prophecy and The Millennium. Essay in Honour of Anthony Gelston (red. P.J. Harland - C.T.R. Hayward) (Supplements to Vetus Testamentum 77; Leiden - Boston - Köln: Brill 1999) 83-99. Davies E.W., Prophecy and Ethics. Isaiah and the Ethical Traditions of Israel (JSOTSup 16; Sheffield: JSOT Press 1981).

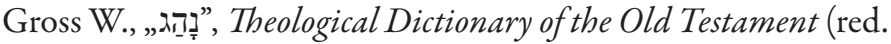
G.J. Botterweck - H. Ringgren - H.J. Fabry) (Grand Rapids, MI: Eerdmans 1998) IX, 255-259. 
Kaiser O., Isaia. Capitoli 1-12 (Antico Testamento 17; Brescia: Paideia 1998).

Kaiser O., Isaia. Capitoli 13-39 (Antico Testamento 18; Brescia: Paideia 2002).

Kellermann D., „קּ ", Theological Dictionary of the Old Testament (red. G.J. Botterweck - H. Ringgren) (Grand Rapids, MI: Eerdmans 1975) II, 439-449.

Kluczyński A.P., „Motyw pokoju między zwierzętami w Księdze Izajasza 11,6-8 i 65,25”, Rocznik Teologiczny ChAT 50 (2008) 9-20.

Kluczyński A.P., „Instytucja monarchii w Izraelu według Iz 10,3311,8 i Mi 5,1-4a", Scripta Biblica et Orientalia 1 (2009) 47-59. Ma W., Until the Spirit Comes. The Spirit of God in the Book of Isaiah (JSOTSup 271; Sheffield: Sheffield Academic Press 1999). Nwaoru E.O., „Building a New World Order: A Perspective from Isa. 11:6-9", Biblische Notizen 119-120 (2013) 132-146.

Oswalt J.N., The Book of Isaiah. Chapters 1-39 (NICOT; Grand Rapids, MI: Eerdmans 1986).

Pikor W., „Pytanie o mesjański sens Izajaszowych proroctw o królewskim potomku. Część II: Iz 8,23b-9,6; 11,1-9”, Zeszyty Naukowe Katolickiego Uniwersytetu Lubelskiego 50/2 (2007) 15-36.

Pikor W., Soteriologiczna metafora wody w Księdze Izajasza (StBL 4; Lublin: Wydawnictwo KUL 2009).

Rumianek R., „Potomek rodu Jessego: Iz 11,1-9”, Studia Theologica Varsaviensia 25/1 (1987) 99-106.

Simian-Yofre H., Testi isaiani dell'Avvento. Esegesi e liturgia (StBi 29; Bologna: Edizioni Dehoniane Bologna 1996).

Stachowiak L., Ksiega Izajasza 1-39. Wstep - przektad z oryginatu - komentarz (PŚST 9.1; Poznań: Pallottinum 1996).

Stansell G., „Isaiah 32: Creative Redaction in the Isaian Tradition”, Society of Biblical Literature 1983 Seminar Papers (red. K.H. Richards) (Society of Biblical Literature Seminar Papers Series 22; Chico, CA: Scholars Press 1983) 1-12. 
Stansell G., „Isaiah: 28-33: Blest Be the Tie that Binds (Isaiah Together)", New Visions of Isaiah (red. R.F. Melugin M.A. Sweeney) (JSOTSup 214; Sheffield: JSOT Press 1996) 68-103.

Steck O.H., „«...ein kleiner Knabe kann sie leiten»”, Alttestamentlicher Glaube und Biblische Theologie. Festschrift für Horst Dietrich Preuss zum 65. Geburtstag (red. J. Hausmann - H.J. Zobel) (Stuttgart - Berlin - Köln: Kohlhammer 1993) 104-113.

Sweeney M.A., „Sargon's Threat against Jerusalem in Isaiah 10,2732", Biblica 75 (1994) 457-470.

Sweeney M.A., Isaiah 1-39. With an Introduction to Prophetic Literature (FOTL 16; Grand Rapids, MI: Eerdmans 1996). Tucker G.M., „The Peaceable Kingdom and a Covenant with the Wild Animals", God Who Creates. Essays in Honor of W. Sibley Towner (red. W.S. Towner - W.P. Brown - S.D. McBride) (Grand Rapids, MI: Eerdmans 2000) 215-225.

Wajda A.M., „Zwierzęta mesjańskiego królestwa (Iz 11,6-9)”, Między Bibliq a kultura. (red. T. Jelonek - R. Bogacz) (Kraków: Wydawnictwo Naukowe Uniwersytetu Papieskiego Jana Pawła II 2011) I, 109-134.

Wildberger H., Isaiah 1-12. A Commentary (CC; Minneapolis, MN: Fortress 1991).

Wildberger H., Isaiah 28-39. A Continental Commentary (CC; Minneapolis, MN: Fortress 2002).

Ks. BARTeOMIEJ Sobier AjSki, kapłan archidiecezji warmińskiej, doktor nauk teologicznych w zakresie biblistyki (KUL), kontynuuje studia biblijne na Studium Biblicum Franciscanum w Jerozolimie. 